\title{
Test Excavations at the Spanish Governor's Palace, San Antonio, Texas
}

Anne A. Fox

Center for Archaeological Research

Follow this and additional works at: https://scholarworks.sfasu.edu/ita

Part of the American Material Culture Commons, Archaeological Anthropology Commons, Environmental Studies Commons, Other American Studies Commons, Other Arts and Humanities Commons, Other History of Art, Architecture, and Archaeology Commons, and the United States History Commons

Tell us how this article helped you.

This Article is brought to you for free and open access by the Center for Regional Heritage Research at SFA ScholarWorks. It has been accepted for inclusion in Index of Texas Archaeology: Open Access Gray Literature from the Lone Star State by an authorized editor of SFA ScholarWorks. For more information, please contact cdsscholarworks@sfasu.edu. 


\section{Test Excavations at the Spanish Governor's Palace, San Antonio, Texas}

Creative Commons License

(c) $)$ (i) @

This work is licensed under a Creative Commons Attribution-NonCommercial 4.0 International License 


\title{
Test Excavations at the Spanish Governor's Palace, San Antonio, Texas
}

\author{
Anne A. Fox
}

with a contribution by

Barbara A. Meissner

Robert J. Hard, Principal Investigator

Texas Antiquities Committee Permit No. 1744

${ }^{\circ}$ copyright

Center for Archaeological Research

The University of Texas at San Antonio

Archaeological Survey Report, No. 259

1997 
The following information is provided in accordance with the General Rules of Practice and Procedure, Chapter 41.11 (Investigative Reports), Texas Antiquities Committee:

1. Type of investigation: Testing

2. Project name: Spanish Governor's Palace

3. County: Bexar

4. Principal investigators: Robert J. Hard

5. Name and location of sponsoring agency: San Antonio Parks and Recreation Department, 950 East Hildebrand Ave., San Antonio, Texas 78212

6. Texas Antiquities Committee Permit No.: 1744

7. Published by the Center for Archaeological Research, The University of Texas at San Antonio, 6900 N. Loop 1604 W., San Antonio, Texas 78249-0658, 1997

A list of publications offered by the Center for Archaeological Research is available. Call (210) 458-4378; write to the Center for Archaeological Research, The University of Texas at San Antonio, 6900 N. Loop 1604 W., San Antonio, Texas 78249-0658; e-mail to car@lonestar.utsa.edu; or visit CAR's Web site at http://www.csbs.utsa.edu/research/car/index.htm. 


\begin{abstract}
Test excavations were carried out in October 1996 by the Center for Archaeological Research of The University of Texas at San Antonio in front of the Spanish Governor's Palace in Military Plaza in downtown San Antonio. Planned for the retrieval of information on the depth and present condition of the foundations of the building, the excavations also recovered important information on previous occupation of the site and construction methods used when the palace was built.
\end{abstract}




\section{Contents}

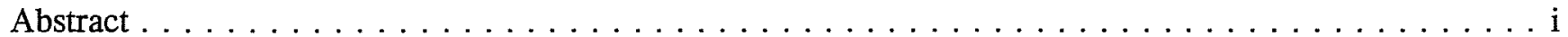

List of Figures $\ldots \ldots \ldots \ldots \ldots \ldots \ldots \ldots \ldots \ldots \ldots \ldots \ldots \ldots \ldots$ iii

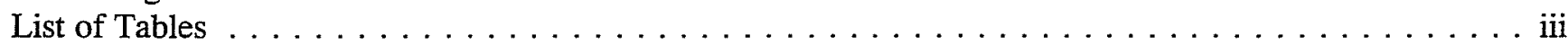

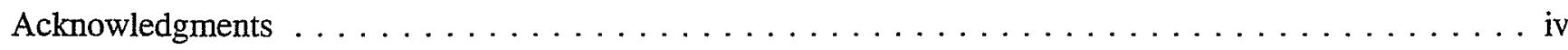

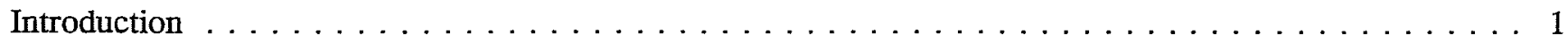

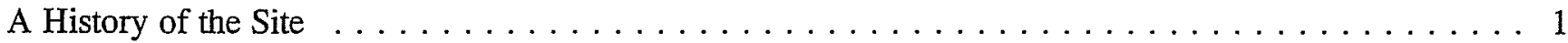

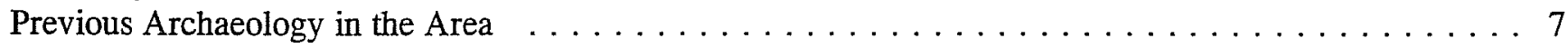

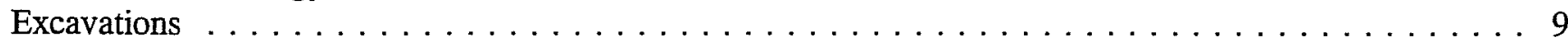

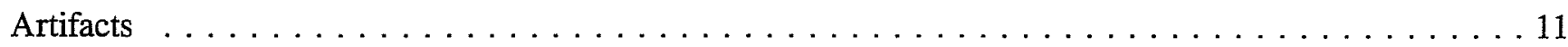

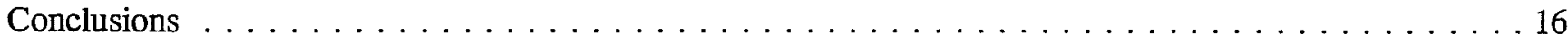

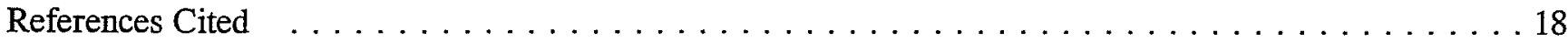

Appendix A: Analysis of Vertebrate Faunal Remains

Barbara A. Meissner . . . . . . . . . . . . . . . . . . . . . . . 21 


\section{Figures}

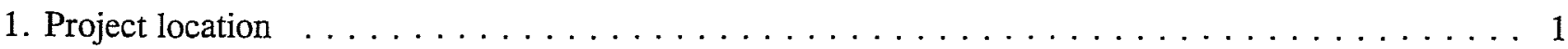

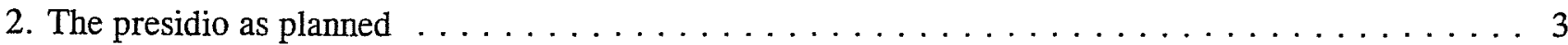

3. Portion of the map Villa and Presidio of San Antonio in $1767 \ldots \ldots \ldots \ldots \ldots \ldots \ldots$

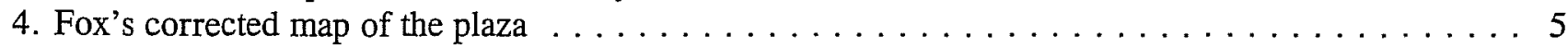

5. Front facade of the Spanish Governor's Palace, prior to restoration $\ldots \ldots \ldots \ldots \ldots \ldots \ldots 7$

6. Back wall and yard of the Spanish Governor's Palace, prior to restoration $\ldots \ldots \ldots \ldots \ldots \ldots 8$

7. Test unit profiles and facade of the Governor's Palace showing test unit locations $\ldots \ldots \ldots \ldots 10$

8. Selected artifacts from the Spanish Governor's Palace excavation $\ldots \ldots \ldots \ldots \ldots \ldots \ldots \ldots \ldots \ldots$

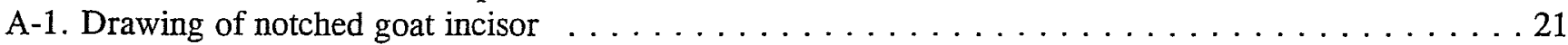

\section{Tables}

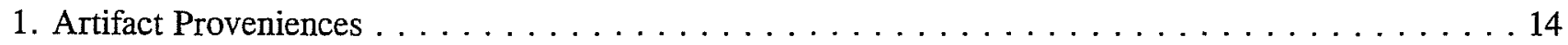

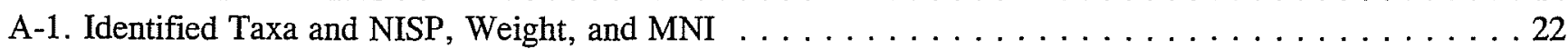

A-2. Identified Taxa Divided into Colonial, Mixed, and Post-Colonial Categories . . . . . . . . . 24

A-3. Domestic vs. Non-domestic Taxa . . . . . . . . . . . . . . . . . . . . . . . 25

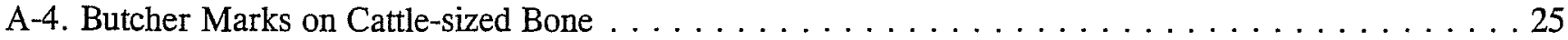




\section{Acknowledgments}

Numerous people were helpful in the planning and execution of this project. We are grateful for the cooperation and guidance of J. Mark Wittlinger, project coordinator for the city of San Antonio Parks and Recreation Department, and to Clint McKenzie of the San Antonio Historic Preservation Office for his aid and comfort. Thanks are also due to architect Charles Schubert and the staff of Rossar Builders who coordinated their work with ours in a cheerful manner.

Robert J. Hard, director of CAR, served as principal investigator. Members of the archaeological crew were students John Arnn, Ed Johnson, Ricky Robinson, and Andrew Scease. The editors of the report were Marcie Renner and Lucy Vasquez, and the illustrations were drafted by Bruce Moses and Fernando Londoño. 


\section{Introduction}

In October 1996, test excavations were carried out by archaeologists from the Center for Archaeological Research (CAR) of The University of Texas at San Antonio at the Spanish Governor's Palace. The palace is located on Military Plaza in downtown San Antonio (Figure 1). The project was conducted for the city of San Antonio under Texas Antiquities Committee Permit Number 1744. The purpose of the excavation was to expose and examine the foundations of the front wall of the Governor's Palace in connection with a city project to repair the roof and exterior walls of the structure.

\section{A History of the Site}

The Presidio San Antonio de Béxar and Mission San Antonio de Valero were founded May 5,1718 , by Martín de Alarcón near the headwaters of San Pedro Creek (Chipman 1992:117). After building temporary

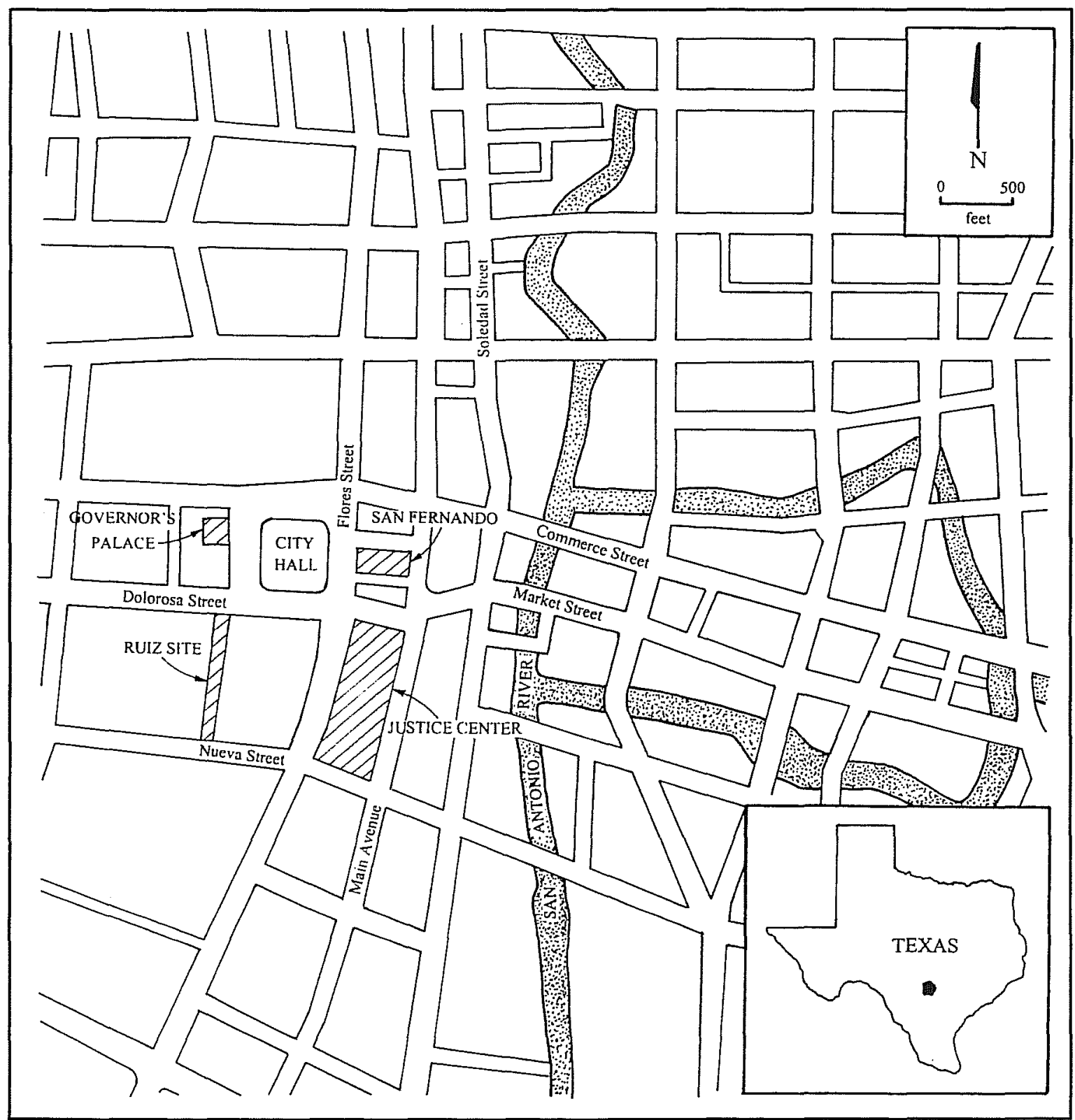

Figure 1. Project location. 
structures, the small group of settlers planted their first crops of maize and vegetables. The maize withered and failed due to a lack of adequate irrigation, and the vegetables were eaten by a plague of rodents. However, by the following January, an acequia was begun and the crops were replanted with greater success (de la Teja 1995:8).

During hostilities between Spain and France, the missions and presidios of East Texas were abandoned and the missionaries and citizens were withdrawn to San Antonio. In 1721 Joseph de Azlor y Virto de Vera, Marqués de San Miguel de Aguayo, governor and captain general of Coahuila and Texas, led an expedition into Texas to return the Spanish presence to the frontier. He reached San Antonio in April and on May 13, accompanied by the exiles, resumed his march to the east where he reestablished and secured the missions (Chipman 1992:121).

On November 17, 1721, Aguayo began the difficult winter march back to San Antonio de Béxar. Plagued by rain and ice storms, the party could often progress only one league a day, and at the last they traveled on foot because the horses were exhausted. By the time they reached San Antonio in late January, the remuda had been reduced to only 50 horses and 100 mules (Foster 1995:155). To compound his woes, Aguayo found that during his absence a raging fire had swept through many of the frail structures of the presidio of Béxar. Sixteen of the soldiers' huts had been destroyed and others damaged; but, worst of all, the granary-with 700 bushels of corn and all the flour-had been lost (Weddle 1968:163). Aguayo had no choice, he dispatched a party to San Juan Bautista on the Rio Grande to resupply both the presidio and the troops. Aguayo's waiting time was not wasted, he immediately ordered a new presidio be built, this time of "fire-proof" adobe. The new presidio was to be constructed further to the south at the big bend of the river, opposite the new site of Mission San Antonio de Valero.

After 43 days, Aguayo was able to resume his efforts for the crown. On March 17, 1722, he departed for Matagorda Bay to reestablish the Spanish presence on the coast of Texas. He established the Presidio Nuestra Señora de Loreto, at the site of La Salle's illfated Fort St. Louis, and the nearby mission of
Espíritu Santo de Zúñiga. Upon his return to San Antonio, in late March, he found that nothing had been done to complete the new presidio. Heavy rains had prevented the men from working and had ruined over 30,000 of the adobe brick that had been produced. Undaunted, he ordered the production of 25,000 more bricks and hired 40 additional laborers for the project, all funded from his own pocket ("Aguayo to His Majesty, June 13, 1722," Archivo de Santa Cruz de Querétaro, 1716-1749. Bolton Translations, Center for American History, Austin).

The new presidio, as envisioned by the governor, was to be "a square with four bulwarks and curtain walls 65 varas [180.5 ft] in length" (Santos 1981:75-76). A surviving plan indicates that the compound was to consist of a fully enclosed square of three concentric rows of buildings with pointed bastions at each of the corners (Figure 2). Ambitious plans of fortified presidios were standard for the frontier; however, few were ever completed as planned. This is certainly the case for San Antonio. There is no evidence that it ever progressed beyond two towers, a surrounding wall and some scattered wooden or jacal structures (Buckley 1911:55). In 1767 the settlement, now augmented by the villa of the Canary Islanders, was described by Pierre Marie Francois Pagés, a captain of the French Navy.

It is encircled by stone walls of the houses which surround it, and the entrances are protected by stone palisades. As the settlement is quite large and some of the houses are ruined, it is not completely enwalled, and it takes quite a lot of people to guard it. . . . The number of houses is perhaps two hundred, of which two thirds are constructed of stone. They are covered by roofs of packed earth which are adequate due to the little rain and the clear skies of this country [Steele 1985:18].

José de Urrutia, captain of the presidio at that time, was quite possibly the resident of the structure later to be called the Governor's Palace. His map of the same date indicates that the building on the west side of Military Plaza crossed the area now occupied by Commerce Street and extended toward the east. The structure under investigation is a portion of the building labeled "Casa del Capitan" (Figure 3). 


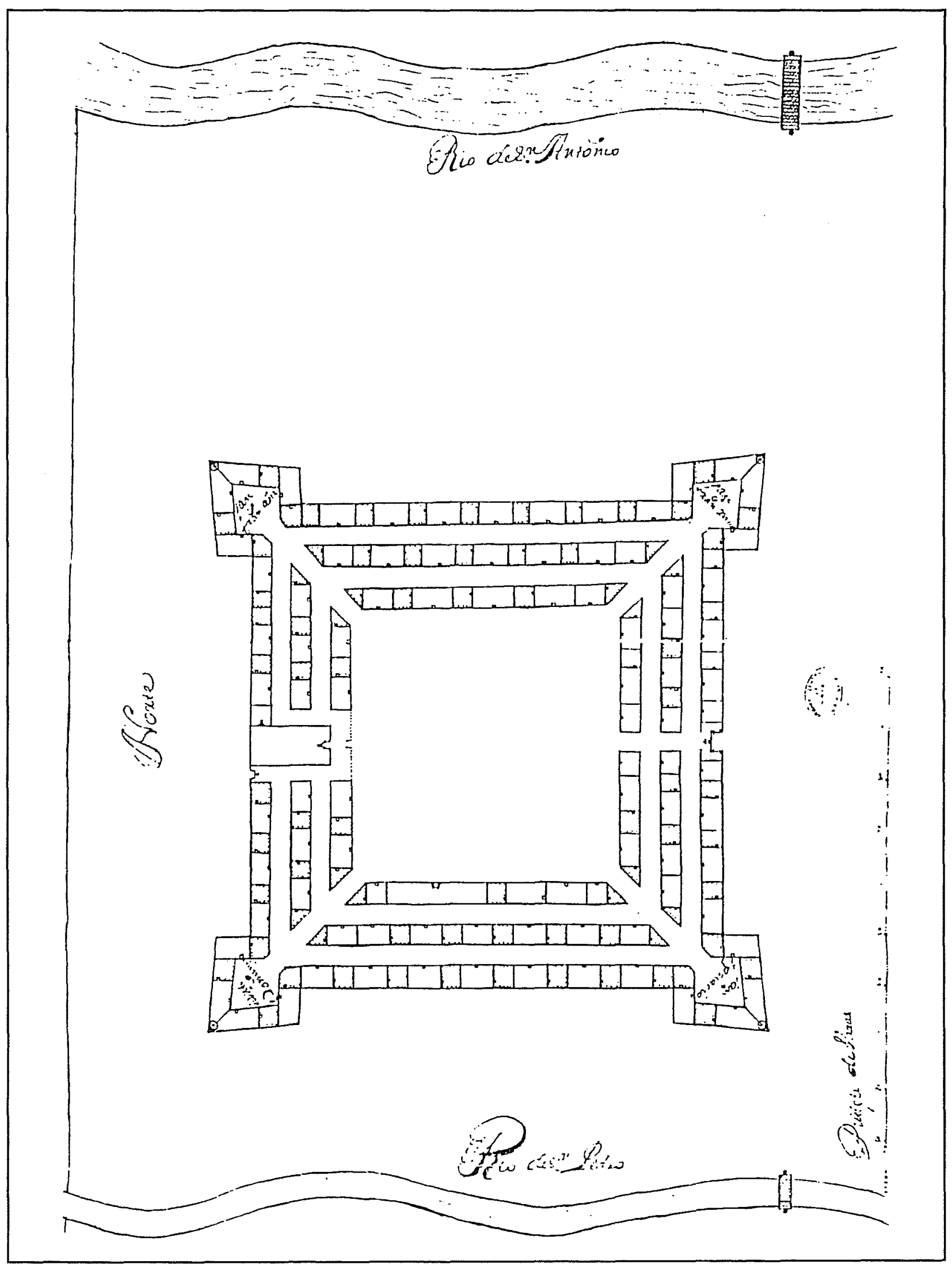

Figure 2. The presidio as planned (from Chipman 1992:124). Facing east. 


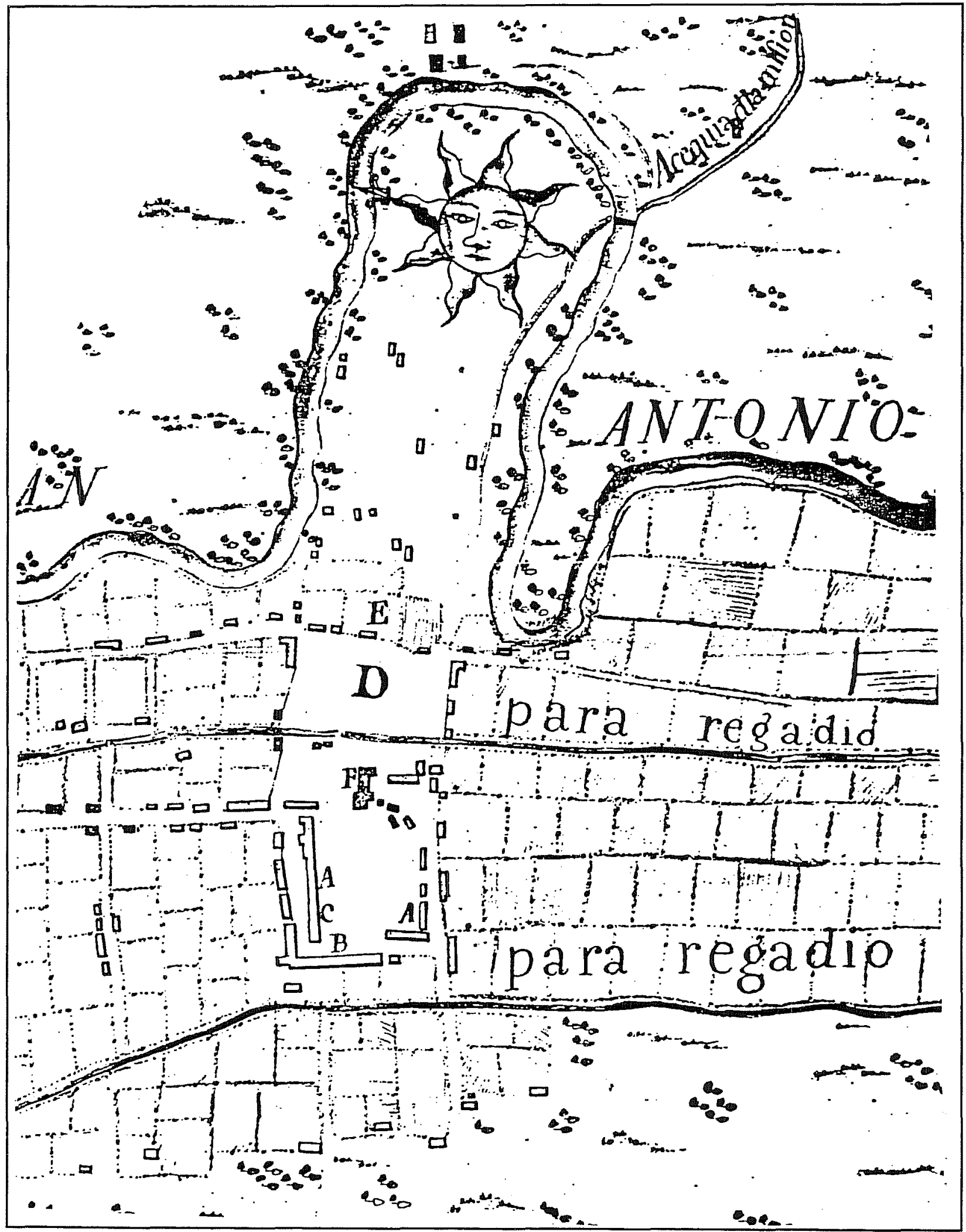

Figure 3. Portion of the map Villa and Presidio of San Antonio in 1767, by Joseph Urrutia. A- Casa del Presidio; B- Casa del Capitan; C-Cuerpo de Guardia; D- Plaza de la Villa; E- Casas Reales; F- Iglesia. Facing east. 
The exact placements of the original presidio structures are not known, but there are strong indications that they occupied an area inside of the present limits of the plaza. This appears to be indicated by the locations of the Casa del Presidio and Cuerpo de Guardia, labeled A and $\mathrm{C}$, on the map. Anne Fox (1977:Figure 2) presented a corrected map of the plaza indicating the most probable configuration in her report of the first archaeological investigations of the site (Figure 4). Further substantiation of this can be found in the records of the city engineer (Giraud 1849:52-53, 56, 69-70).

The exact date of construction of the building under investigation is not clear. The keystone over the main

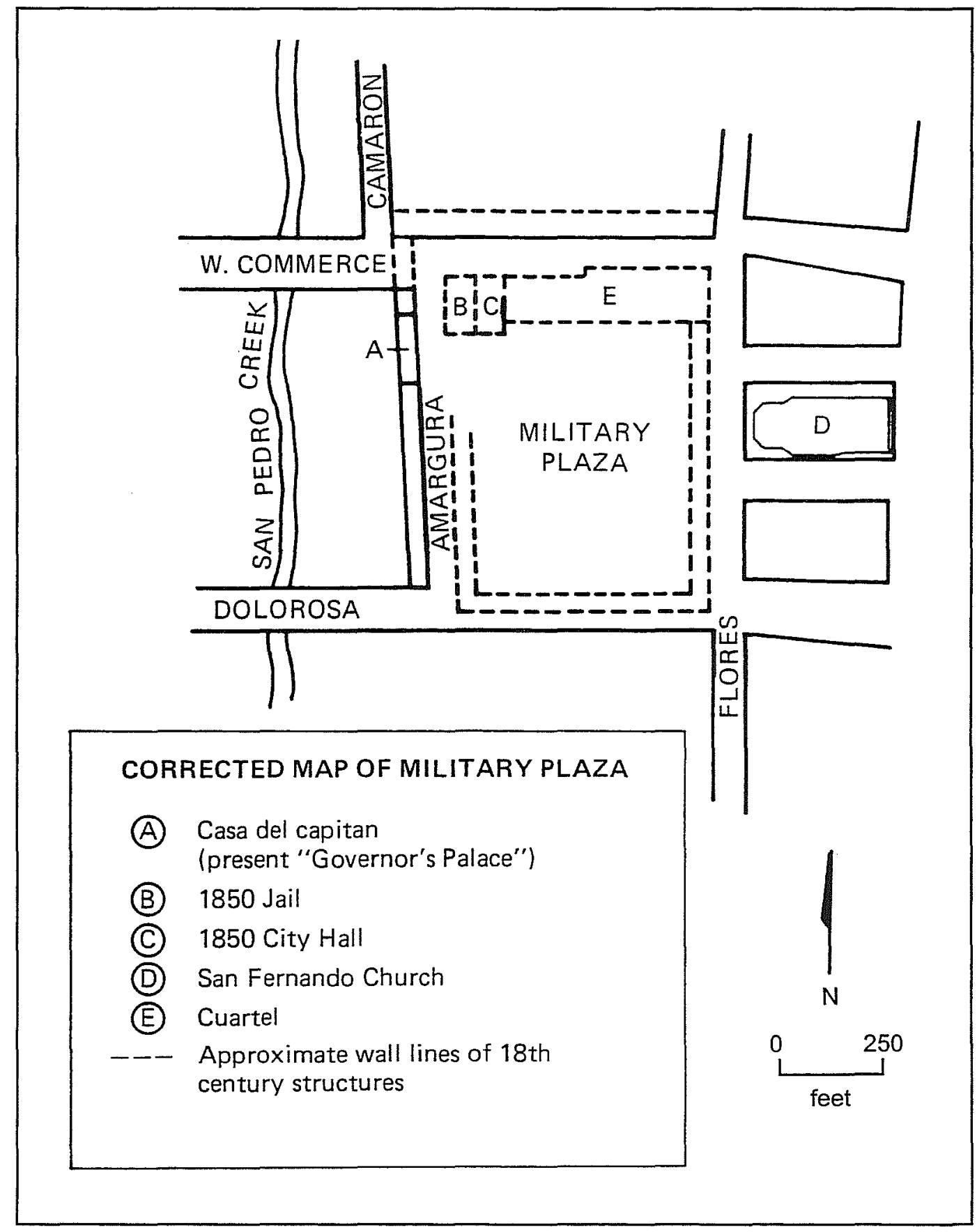

Figure 4. Fox's corrected map of the plaza (from Fox 1977:Figure 2). 
entrance bears the Hapsburg coat-of-arms and the date "ANO 1749," but this could indicate the construction date or the completion of modifications. Governor Navarete, in 1762, indicated that his office was located in the house of the captain and described it as "stone or rubble and mortar, and a very strong edifice" (Ramsdell 1959:122). By the mid to late 1700 s the property had passed into private ownership. A grant issued in 1778 for the property to the north indicated that the site was already in the possession of Luis Antonio Menchaca (Chabot 1937:21).

Luis Antonio Menchaca was the son of Antonia de Urrutia, daughter of Captain José de Urrutia; therefore, it is possible that the Governor's Palace property passed from her father as a portion of her inheritance. Menchaca's father, Francisco, served under Governor Martín de Alarcón and was with the original garrison at the founding in 1718. Luis became one of the earliest and most substantial ranchers in the area. His Rancho de San Francisco was one of the oldest and largest grants in Texas (Jackson 1996a:617). Upon Luis's death in 1793, the Governor's Palace property passed to his son, José (Menchaca Will, 1803, Wills and Probate, Bexar County Archives [BCA], microfilm, San Antonio Main Library, San Antonio, Texas).

José Menchaca followed in his father's footsteps, rising to the rank of captain in the Béxar presidial company, and saw duty in Coahuila prior to his retirement in 1801. In 1811 he joined with Bernardo Gutiérrez de Lara, a supporter of Hidalgo, to organize a revolutionary movement against Spain. He was captured, tried, and imprisoned in Chihuahua, where he died in 1820 (Jackson 1996b:616-617).

When José Menchaca retired in 1801, he conveyed the Governor's Palace property to Juan Ygnacio Pérez for 800 pesos ("Sale of a stone house by Joseph Menchaca to Ygnacio Perez-1804," Land Grants and Sales, BCA). During the revolution, Ygnacio Pérez remained strongly royalist and served as captain of cavalry under General Arredondo in the decisive Battle of Medina. During the tumultuous period that followed, he distinguished himself defending the weakened province and served as interim governor from July 1816 to March 1817. Ygnacio died October 7, 1823 (Jackson 1996c: 149-150).

When Ygnacio purchased the Governor's Palace property from Menchaca, the house was "bounded on the East by the guard house and the Plaza de Armas" and "consist[ed] of a living room, another room, a bedroom, two hallways, and a kitchen entirely built of stone, with four stone door casements" (Menchaca to Perez, 1804, Land Grants and Sales, BCA). The deed also states that the property to the north, a portion of the same structure, belonged to Maria Luisa Guerrero. She had acquired it from her husband, Jacobo Hernández (Chabot 1937:35). This property was acquired, in 1819 , by Ygnacio for 350 pesos (San Antonio Express [SAE], 2 January 1929).

Ygnacio Pérez's daughter, Maria Gertrudis, at age 24, married Manuel Antonio Cordero y Bustamante, former governor of Texas, age 61. The couple resided in the Spanish Governor's Palace. After Manuel Cordero's death, Maria married, in 1833, the dashing José Cassiano. Cassiano, born Giuseppe Cassini in San Remo, Italy, came to Texas in the 1820s. During the Texas Revolution, he served as a scout and reported on the movements of General Antonio Lopez de Santa Anna to William B. Travis in the Alamo. He contributed generously to the revolution and served as an alderman in San Antonio at various times during the period of 1839-1846 (Strong 1996:1015).

By the mid-1800s the area around the Governor's Palace had ceased to be a prominent residential area and the Cassiano family had moved to their ranch property on the Medina River. The old homestead had turned to commercial property. In June 1872 , the owner at that time, Trinidad Pérez, leased the property to Charles Guerguin for a period of eight years for a rental fee of $\$ 10$ per month. She further required that specific repairs be made as a condition of the lease. Among the repairs demanded were a new tin roof, new windows and blinds facing the plaza, a wooden partition in the "salle or main room," a new plank floor and pantry in the corridor, a new chimney in the kitchen, and the structure "whitewashed inside and out" (Bexar County Deed 
Records [BCDR], Bexar County Court House, San Antonio, Texas, Volume XI:28). The following month, she amended the lease for two additional years for further repairs, including a new stone wall and fireplace in the rear room (BCDR W2:350). On September 30, 1898, Trinidad Pérez deeded the property to her niece, Concepción, and her niece's husband for $\$ 5.00$ and "the love and affection I bear my nephew and niece" (SAE, 2 January 1929).

By 1915 a group of citizens became concerned over the destruction of much of the city's historic heritage. The Texas Historical and Landmark Association, created by Adina De Zavala, began appealing for funds to save the crumbling structure-the only remaining major Spanish-era building. The newly formed Conservation Society lent its support, but the effort remained stalled. In 1924, the heirs received an offer of $\$ 57,000$ for the property by developers in New York. Alarmed by this news, the City Federation of Women's Clubs appealed to Mayor Tobin to purchase the building; the issue was added to a city bond election, but was cut when the bond issue was trimmed by onethird. Finally, with continued pressure from these groups, Mayor Chambers backed a $\$ 55,000$ purchase item in the $\$ 4.8$ million bond issue of 1928, which was passed (Fisher 1996:123-125). In 1929 Frank F. and Concepción Walsh conveyed the property to the city of San Antonio (BCDR).

\section{Previous Archaeology in the Area}

At the time of the city's purchase, the Governor's Palace was in need of extensive repairs (Figures 5 and 6). The first recorded excavations done on the site of the Governors's Palace were supervised by architect Harvey P. Smith, Jr., in July 1929, in connection with the restoration of the structure. Smith wrote several accounts-published by the San Antonio Express and several national magazines-of the work done at that time. By combining the information in these references, it is possible to reconstruct what Smith did. In the Pan American Magazine, Smith is quoted as saying,

Reconstructing the palace was really more of an archaeological than an architectural problem. So many of the original walls had fallen and so many changes had been made by tenants during comparatively recent years that in many cases we had difficulty in finding the original line of the wall. When in doubt we excavated to a depth of three or four feet until we came to the original foundations. We could tell which were the old walls by their width, the materials used and the workmanship [Martin 1931:190].

When the work began, Smith reported that "only the front wall and small portions of one or two walls

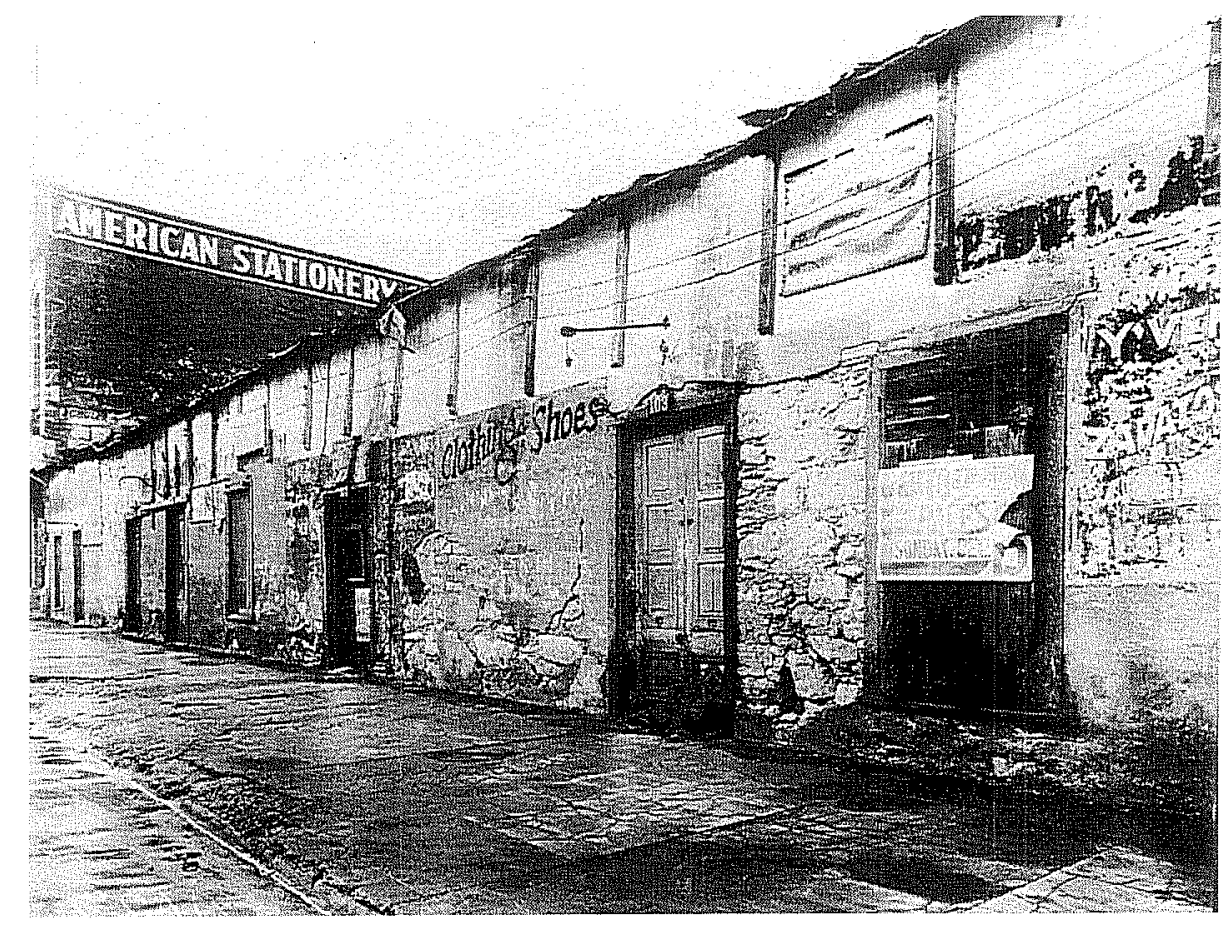

Figure 5. Front facade of the Spanish Governor's Palace, prior to restoration. Looking from the west. From the San Antonio Light (22 December 1929) collection, the Institute of Texan Cultures. 


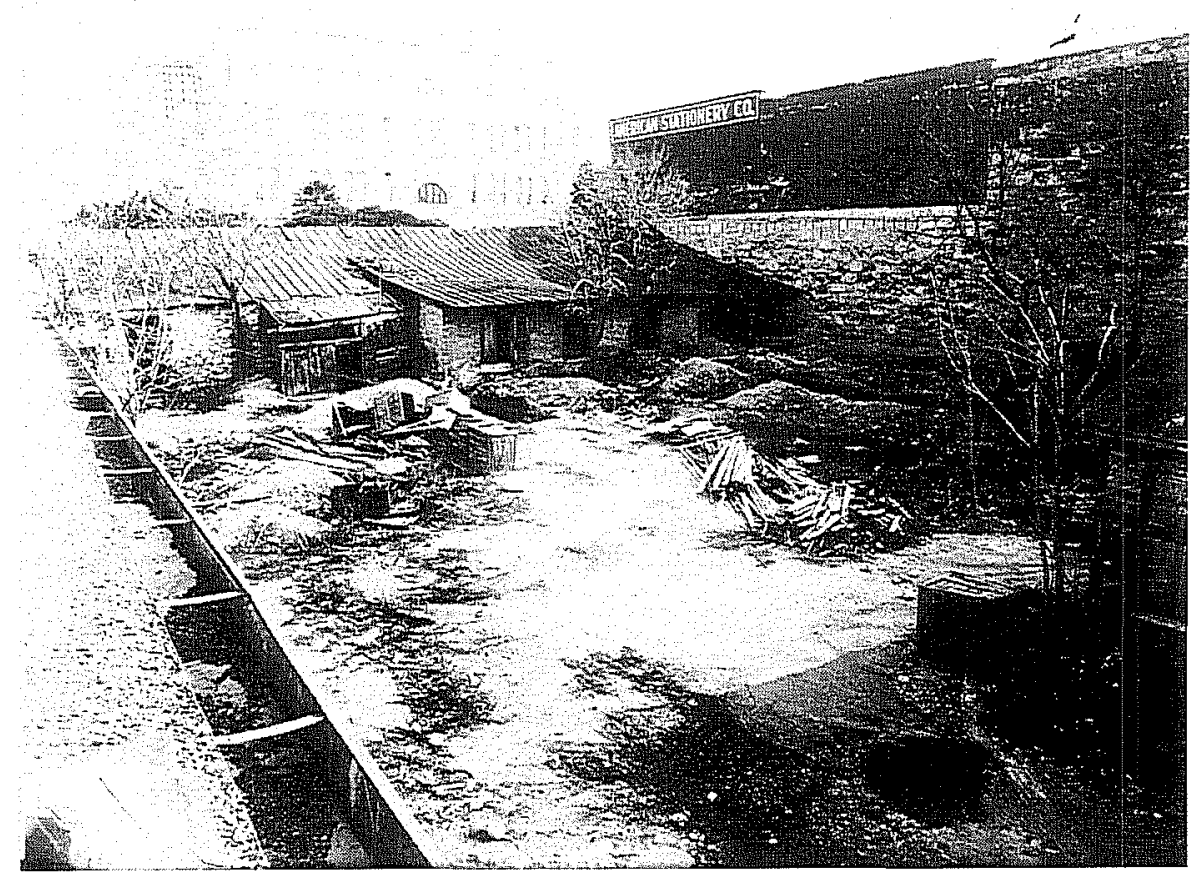

Figure 6. Back wall and yard of the Spanish Governor's Palace, prior to restoration. Looking from the west. From the San Antonio Light (22 December 1929) collection, the Institute of Texan Cultures.

directly behind" existed (Smith 1931a:30). In another article he described his excavation methods in more detail,

We started from the few old walls in the rear that were in a dilapidated condition, and digging down to the original footings of these, we started trenches out in various directions, where we found that stone footings extended from the original walls, and in this way we located, and thereby had positive proof of, the rooms we added in the rear [Smith 1931b:4A].

From these various descriptions, it appears that Smith did the best job he could given the state of knowledge at the time. Furthermore, his restoration is probably accurate.

Other archaeological investigations in the general area include 1975 excavations in the floor of San Fernando Cathedral across the Plaza from the Governor's Palace. A crew from the State Archeologist's Office, testing in conjunction with a renovation project, recorded the foundations of the original church beneath the present cathedral floor and recovered artifacts predating the church's construction (Fox 1977).

In 1976 CAR archaeologists conducted test excavations directly north of the north wall of the Governor's Palace, where the city was planning to construct a small public park. The tests indicated that the only remaining portion of the original presidio building that had once continued north through the area had been badly disturbed by a later reinforced-concrete foundation (Fox 1977). A very small area within the original structure preserved in this corner contained sections of two successive floors and the deposits between them.

Across from the southwest corner of Military Plaza, CAR conducted archaeological testing in advance of the construction of the Bexar County Justice Center from 1978 to 1987. Archaeologists examined foundations of numerous eighteenth- and nineteenthcentury structures and exposed and tested a section of the original San Pedro acequia (Fox et al. 1989). The 
dates of the buildings investigated ranged from the 1820 s to the mid-twentieth century.

In 1989 a CAR crew of archaeologists conducted test excavations on the property of the Ruiz family on the south side of Military Plaza (Uecker et al. 1991). Foundations of the late-nineteenth-century home of a descendant of a family of political importance during the eighteenth and early nineteenth centuries in San Antonio were uncovered and mapped, along with the family's brick-lined privy.

Of these various excavations, the one that took place directly to the north in 1976 provided the most help in understanding what was found during this project. The Colonial levels revealed in the current excavations corresponded well with those found in 1976 , and the artifacts recovered were quite similar. However, the foundations of the main body of the Governor's Palace extended deeper into the ground than those of the addition to the north, suggesting that the two structures were not built at the same time.

\section{Excavations}

All test units were located against the front wall of the building (Figure 7). Each was centered on the drain from a downspout running from the roof level to a pipe beneath the sidewalk, thence to the street. The sidewalk consisted of the original sandstone paving stones installed over a layer of gravel at the time of the restoration, over which a concrete sidewalk had been laid at the time of the park construction in 1977. The contractor removed a three-foot-square hole in the sidewalk at each unit location and removed the sidewalk materials and part of the gravel base beneath. The surface of the most recent sidewalk was used as a point of reference from which to measure the depths of the excavation levels.

\section{Unit A}

Unit A, measuring $3 \times 3 \mathrm{ft}$, was located at the north corner of the building facade (Figure 6). The remaining gravel was removed to the top of a deposit of light brownish gray (10YR 6/2) friable soil.
Excavation then proceeded in six-inch levels to the bottom of the building foundation.

Levels $1 \mathrm{a}$ (7-10 inches) and $1 \mathrm{~b}$ (10-13 inches) were confined to three inches until the crew became familiar with the stratigraphy of the site. In each case, the soil was as described above and contained plaster and sandy mortar fragments, window glass, and wire nails.

Level 2 (13-19 inches) started in the same soil, but contained numerous chunks of limestone three to five inches in diameter. At 16 inches, charcoal appeared along with a mixture of small sherds of English and Mexican ceramics, animal bone, and glass fragments. The top of the foundation appeared at 18.5 inches. This was indicated by the protrusion of the foundation three inches out from the building wall.

Level 3 (19-25 inches) was capped by a thin layer of caliche which was followed by more of the same soil as above to 21.5 inches. At this point the soil color changed abruptly to very dark grayish brown (10YR $3 / 2$ ). Near the point of contact, but in the lighter-colored soil, were over 100 fragments of a dark green wine bottle and a sherd of late-eighteenthcentury majolica. In the next 2.5 inches were numerous pieces of bottle glass, English ceramics, and some Mexican sherds, all post-1900 in date.

In Level 4 (starting at 25 inches), excavation was confined to an eight-inch trench against the foundation. The bottom of the foundation was found at 42 inches below the present sidewalk.

\section{Unit B}

Unit $\mathrm{B}$, measuring $3 \times 3 \mathrm{ft}$, was located near the center of the facade (Figure 6). We decided to continue with six-inch levels, recording soil changes as they occurred.

Level 1 (7-13 inches below sidewalk) began in a nearly white soil (10YR $8 / 2$ ), changing at nine inches to a dark grayish brown sandy clay (10YR 3/2) containing metal scrap, animal bone, and wire nails. 


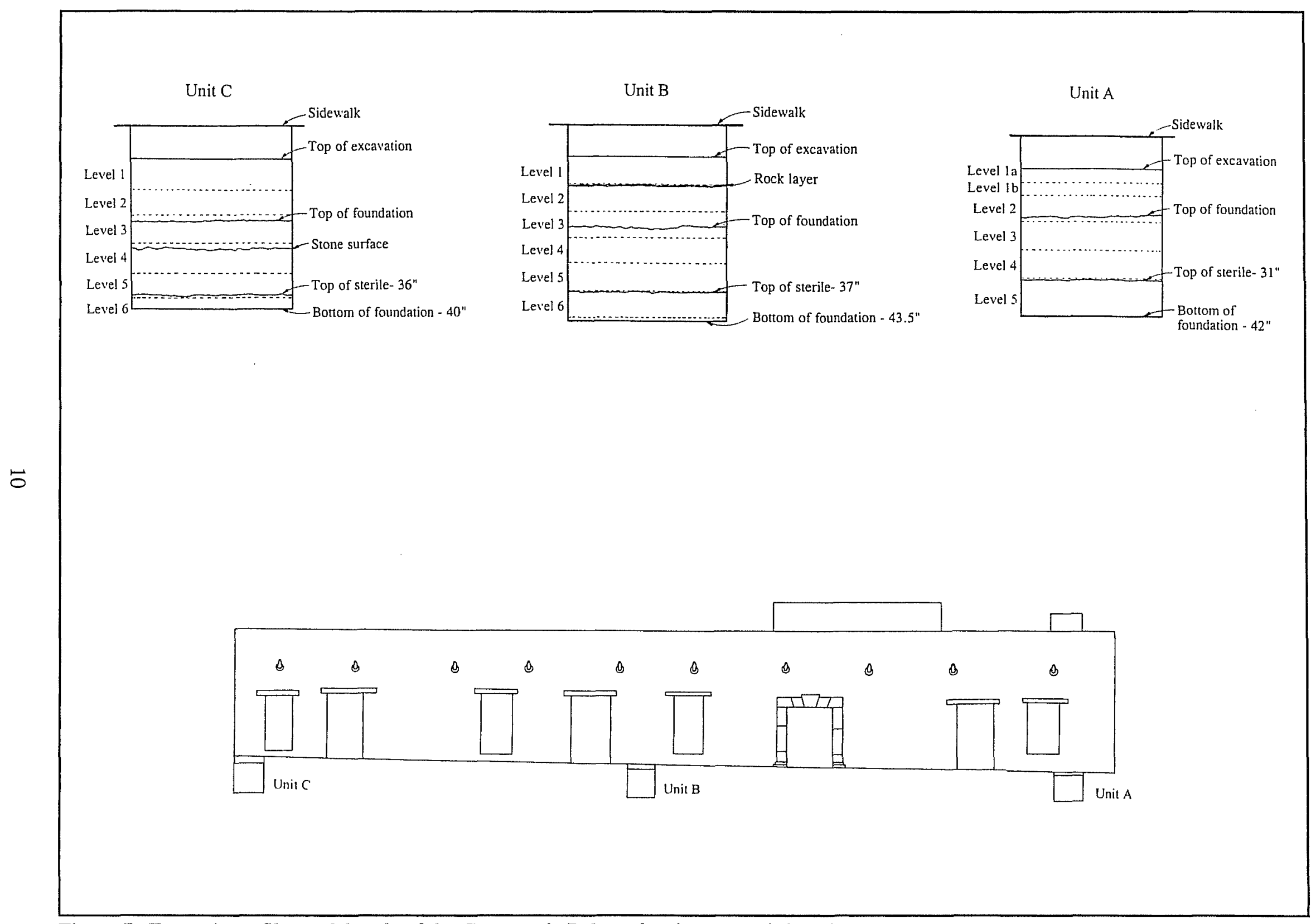

Figure 7. Test unit profiles and facade of the Governor's Palace showing test unit locations. 
Level 2 (13-19 inches) consisted of the same sandy brown clay, changing at 19 inches to a layer of small stones which resembled a floor or occupation surface. At this point the wall protruded ca. 1.5 inches into the unit, an indication of the top of the foundation, as found in Unit A. The contents of this level included both Mexican colonial and early nineteenth-century artifacts mixed together.

Level 3 (19-25 inches) contained river cobbles and artifacts primarily from the last half of the eighteenth century. The soil continued to be very dark grayish brown, moist, sandy clay.

Level 4 (25-31 inches) continued in the same soil. Only the west half of the unit was excavated. Colonial artifacts continued, but in a much smaller amount.

Level 5 (31-37 inches) continued in the same soil. Only the west half of the unit was excavated. Colonial artifacts continued to decline.

Level 6 (37-44 inches) encountered sterile, clay soil slightly lighter in color (10YR 4/2). The bottom of the foundation was found at 43.5 inches.

\section{Unit C}

Unit C was slightly larger, $40 \times 36$ inches, following the excavation in the sidewalk. It was located at the south end of the facade of the building, its south edge on the line of the north end of the building next door (Figure 7).

Level 1 (7-13 inches below the sidewalk) excavations began at the top of the light brownish gray (10YR 6/2) sandy clay soil. Artifacts recovered included glass, nails, plaster, metal scrap, a fragment of ceramic sewer tile, and some animal bone.

Level 2 (13-20 inches) continued in the same soil to 18 inches, where a compacted surface was found. Embedded in and below this surface was a mixture of Mexican and Indian sherds, bottle glass, metal scrap, window glass, nails, and animal bone.
Level 3 (19-25 inches) encountered the top of the foundation at 22 inches, although the foundation did not project from the face of the wall at this point. It was possible to distinguish the foundation from the wall by a definite break in the type of construction and the shape and size of the stones. A few Colonial ceramic sherds, some bone, and chert fragments were present in this level.

Level 4 (25-31 inches) encountered slightly darker grayish brown (10YR 5/2) soil. At 28 inches, a surface composed of small stone chips was recorded, and below this was found a large amount of Colonial ceramic sherds, over $460 \mathrm{~g}$ of animal bone, a Spanish colonial rein chain link, and 21 chert fragments-a totally Colonial deposit.

Level 5 (31-37 inches) continued in dark grayish brown (10YR 4/2) clay which contained more Colonial ceramic sherds, animal bone, an olivella shell bead, a musket ball, and chert fragments. The soil became sterile at 36 inches.

Level 6 (37-40 inches) consisted of an eight-inch-wide test trench excavated against the foundation. The bottom of the foundation was found at 40 inches.

\section{Artifacts}

In a limited testing project such as this one, the artifacts primarily contribute to the identification and dating of deposits. For these purposes, ceramics are the most closely dated and most securely identified with particular ethnic groups which occupied a specific site. Ceramics in the San Antonio area can be roughly divided into eighteenth- and nineteenthcentury categories, and have been used in the following discussion to separate mixed deposits from purely eighteenth-century Spanish colonial deposits. Preliminary judgments based on ceramics can then be reinforced by identifying and roughly dating other artifacts found in the same level or stratum. Selected artifacts are illustrated in Figure 8.

Artifacts other than ceramics can be grouped into general periods. For instance, eighteenth-century 


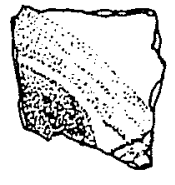

a

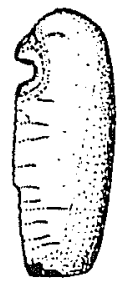

e

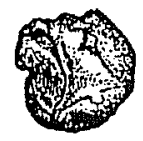

i

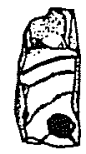

b

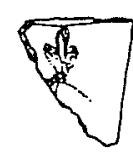

c

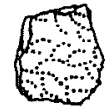

d

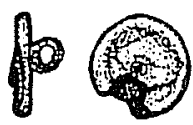

f

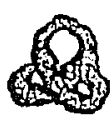

g

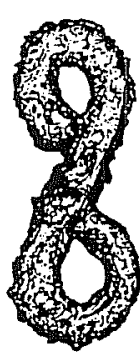

h

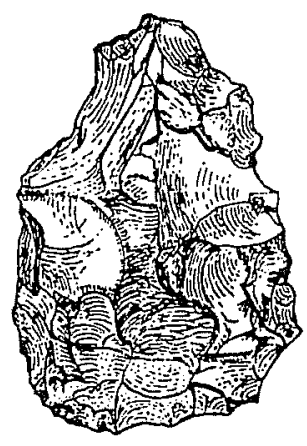

k

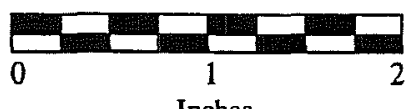

Inches

Figure 8. Selected artifacts from the Spanish Governor's Palace excavation. a- lead-glazed ware; b- Puebla Polychrome; c- hand-painted white earthenware; $d$ - transfer-decorated white earthenware; e- Olivella shell bead; f- brass button; g- clothing fastener; h- chain link; i- musket ball; j-forged nail; $\mathrm{k}$ - chert tool. 
Spanish colonial collections usually include copper fragments, hand-forged nails, fragments of olive green wine bottles, chert tools and fragments, horse equipment, musket parts, and hand-made brick. Nineteenth-century San Antonio occupations, which can include both Hispanic and Anglo-American residents, typically include fragments of hand-blown glass containers; thin, rusted metal; smoking pipes; buttons; thimbles; window glass; and cut nails. This type of occupation can be roughly divided into preand post-Civil War periods by the ceramics present.

\section{Ceramics}

The ceramic sherds recovered from this project were all very small, making it nearly impossible to identify vessel shapes. The following types found during the Governor's Palace excavations (Table 1) were identified by the presence or absence of glaze and by surface finish. The mission collections in the CAR laboratory were used for comparisons.

\section{Unglazed Wares}

Two types of unglazed ware are commonly found on San Antonio sites. Goliad ware, a handmade, low-fired ware usually tempered with bone, was made by the mission Indians but came to be used in the town as well in the eighteenth and early nineteenth centuries (Fox et al. 1976:67; Ivey and Fox 1981:31). A wheel-turned buff-colored ware has been locally termed Valero ware (Fox et al. 1976:67; Ivey and Fox 1982:39). This type was present in San Antonio from ca. 1730 to 1760 .

\section{Burnished Wares}

A few sherds of unglazed burnished wares are usually found on eighteenth-century San Antonio sites. One variety has a dark red body with matte designs on a burnished surface. Another has a tan body painted with delicate designs in red, yellow, and black. The latter has been identified as coming from Tonalá, Jalisco, and is commonly called Tonalá bruñida ware.

\section{Lead-Glazed Wares}

Two general types of lead-glazed wares are common on sites in the San Antonio River Valley. A sandy paste ware comes in various shades of green and yellow, with occasional green bands on yellow (Figure 8a). A thin, red orange ware often decorated with dark brown, green, and cream has no visible tempering. The former type appears to be present throughout the mission period, while the latter, consistently called Galera ware across the Southwest from Texas to California, does not appear until the last half of the eighteenth century.

Tin-Glazed Wares

A type of earthenware introduced into Mexico by the Spanish, tin-glazed or majolica ware, has provided a convenient method of dating Colonial deposits. This ware is present in varying amounts on every Spanish colonial site from Florida to California, and the changes in patterns over time create a timetable for archaeologists. The unusually small size of the sherds recovered from this site (averaging $1 / 4$ to $3 / 8$ inch across) make identification of many common patterns very difficult. The most important observation that can be made is the presence in Unit C Level 5 of a sherd of Puebla Polychrome (Figure $8 \mathrm{~b}$ ) which, according to most authorities, was not made after 1725. This type has also been found at quite some depth in other areas close by, including beneath San Fernando Cathedral (Fox 1977) and the Bexar County Justice Center (Fox et al. 1989). A sherd of this type was also found near the bottom of a test pit outside the back wall of the Palace extension to the north (Fox 1977:9).

White Earthenware

British-made white earthenware began appearing in San Antonio during the first quarter of the nineteenth century, probably partly as a result of the radical changes that took place at the time of the Mexican revolution. Brightly colored sherds of this ware caused an immediate change in the artifact collections at about this time, when the ceramic factories in Mexico were floundering because of the flood of British wares on the market. This type (Figure 8c, d) appears in the 13-25 inch levels of this site, just above the undisturbed Spanish colonial levels.

Porcelain

A few sherds of European porcelain are generally found in the same levels as the British earthenwares, and this was true of Unit $A$. The fragments are much too small for further identification. 


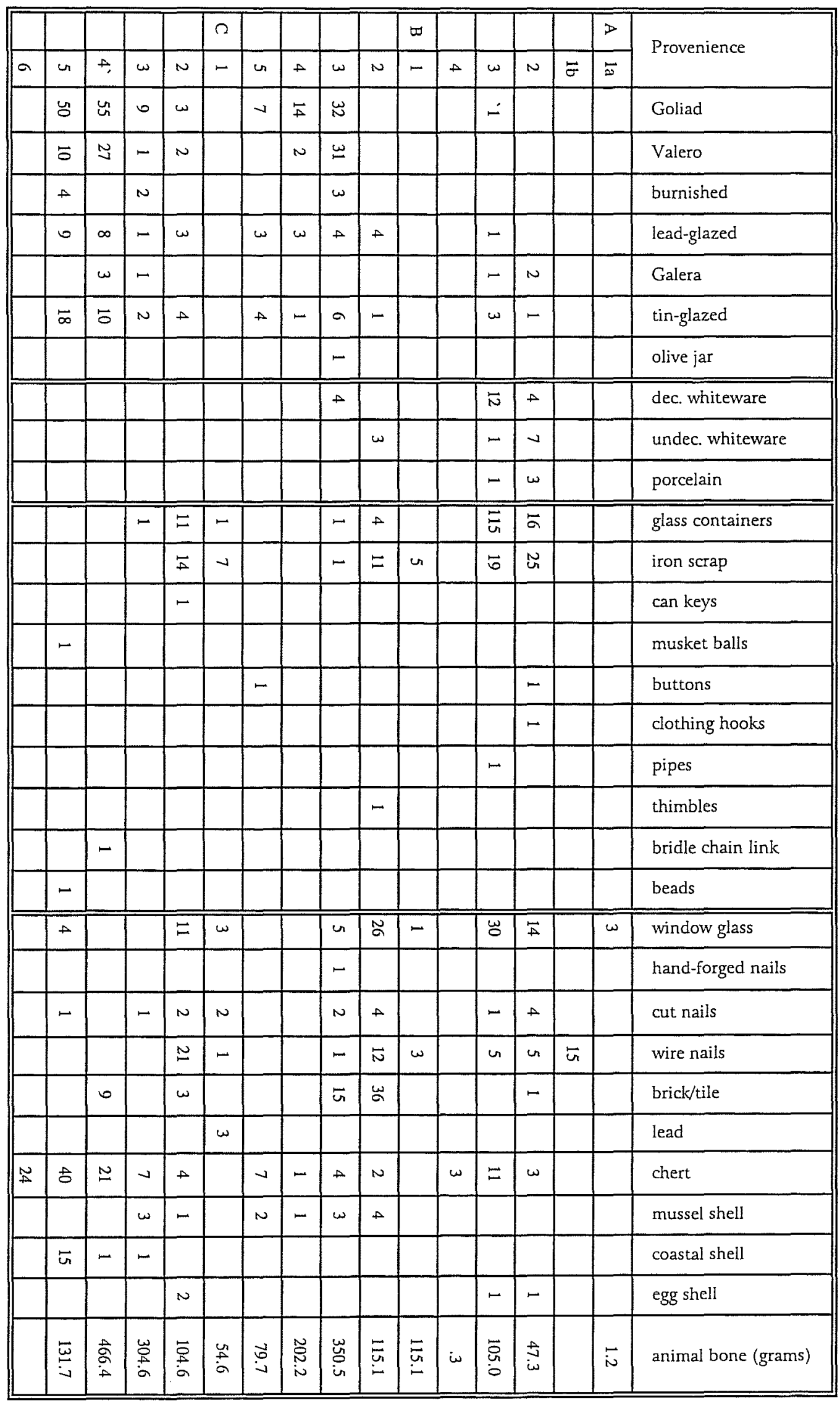




\section{Glass}

Fragments of bottle glass were found primarily in the upper levels of the excavation. Few pieces were large enough to identify the vessel shape or age, but the numerous fragments from Level 4 in Unit A appear to have come from one olive green wine bottle, probably of Colonial vintage.

\section{Personal Items}

Beads

A portion of an olivella shell bead (Figure 8e) was recovered from the Colonial level in Unit C. Beads of this type are frequently found on mission sites in San Antonio. Similar beads have also been found on Karankawa Indian sites on the Texas coast (Schuetz 1969:75-76).

\section{Buttons}

An undecorated, compound brass button (Figure 8f) came from Level 3 in Unit A. A loop was brazed to the back. It probably dates to the early nineteenth century. A white, four-hole ceramic button, $3 / 8$-inch in diameter, was found in Level 3 of Unit A. This fits comfortably within the early nineteenth-century artifacts from this level.

\section{Clothing Hook}

The eye half of a clothing fastener (Figure 8g) came from the same location. This type of two-piece "hook and eye" was introduced in the nineteenth century and continues in use today.

Pipes

Six fragments of a small, brown ceramic tobacco pipe were found in Level 4 of Unit A. Similar pipes have been found in nineteenth-century sites throughout the San Antonio area.

Thimble

Four fragments of a brass thimble were found in Level 2 of Unit B. Such objects are often found in nineteenth-century sites.

\section{Metal}

Chain Link

One S-shaped link (Figure 8h) from a rein chain or cabestrillo (Simmons and Turley 1980:101) came from Level 4 in Unit C. Identical chain links have been found on other Spanish sites in Texas.

Musket Ball

A lead ball, roughly $1 / 2$-inch in diameter and weighing $1,735 \mathrm{~g}$, was found in Level 5 of Unit C. It is flattened on one side and badly out of shape, perhaps from hitting the facade of the building.

Miscellaneous

Numerous fragments of thin, rusted metal came primarily from the upper levels of all three units. They are not identifiable as to what type of objects they represent. However, the presence of a can-opening key indicates that some of the scraps are probably from tin cans.

\section{Construction Materials}

\section{Hand-Made Brick}

Fragments of locally made brick/tile (ladrillos) were found throughout the area. These all appear to date to the Colonial period, perhaps lapping slightly into the early nineteenth century. They were used frequently in the missions for flooring and for repair of the walls and doorways (Fox 1992:62).

Forged Nail

One hand-forged nail (Figure 8j) came from Level 3 of Unit B. Such nails were made and used in Colonial times.

Other Building Materials

Various building materials were found within the test units, most of which can be confidently linked to the construction and repair of the Governor's Palace. Included among these are window glass of various thicknesses, cut and wire nails, several types of wire, and lead fragments from plumbing activities. 


\section{Miscellaneous}

\section{Chert}

Chert flakes and fragments resulting from the manufacture of tools and projectile points in the Late Prehistoric period carry through into the early eighteenth century in downtown San Antonio. Although no projectile points have been found in this particular area, evidence of the continued use of chert for making cutting and scraping tools has been found, the most notable from the 1976 excavations just to the north of the Governor's Palace (Fox 1977:15). A chert tool from Level 4 in Unit C (Figure 8k), from which the pointed tip has been snapped off, appears to have been originally intended as a drill.

\section{Mussel Shell}

A few fragments of river mussel shell were recovered from the lower levels of Units B and C. Similar fragments are commonly found in most excavations in the area (see Schuetz 1969:76).

\section{Egg Shell}

Chickens have been present in San Antonio since the early eighteenth-century founding of the missions. Their egg shells are commonly found from that time to the present throughout the city. A few small pieces of egg shell came from Units A and C.

Coastal Shell

Evidently the early residents of San Antonio either traveled as far as the Texas coast or traded with the people of that area. Coastal shells and fragments are not uncommon on the mission sites in the vicinity, along with beads and other artifacts from that area (Schuetz 1969:76). Seventeen coastal shell fragments were found in the lower levels of Unit C.

\section{Faunal Remains}

Almost 2,000 faunal remains were recovered in the Governor's Palace excavation. The analysis, which identified 24 taxa, is presented in Appendix A.

\section{Conclusions}

These excavations were conducted to examine the condition of the foundations of the Spanish
Governor's Palace and to determine their depth. We found that the foundations extended 40-43 inches below the level of the top of the present sidewalk, and that they appear to be in excellent condition, and have not been disturbed since they were originally constructed. Additional information important to understanding the construction of the building in the early eighteenth century and its remodeling by architect Harvey P. Smith in 1929 was revealed. Based on our findings, we can make the following statements.

The building was apparently constructed on a site which had previously been occupied. Evidence for the excavation of the foundation trenches into soil already containing Spanish colonial artifacts is seen in the fact that such artifacts were found in Level 3 mixed with later materials, and in a pristine early Colonial context just below the top of the foundation in Level 4. Evidence from the three units indicates that this early accumulation intensifies as we progress north to south from Unit A to Unit C (see Table 1). This suggests that the earlier occupation was concentrated from Unit $\mathrm{C}$ toward the south. This would also have been the highest point in the area, judging from the gradual north-south rise $(1.5 \mathrm{ft})$ in the sidewalk between Units $\mathrm{A}$ and $\mathrm{C}$.

The foundation was probably constructed in the following manner. A trench about 24 inches deep was dug on the outlines of the entire building. Using the trench as a form, the foundation was constructed by laying stones in the trench and shoveling or pouring in sand and lime mortar around them. The top of the foundation was then leveled off. Finally, the walls were constructed on top of the foundation. James Ivey (et al. 1990:56) suggests that this method was customarily used for "more substantial buildings" during the mission period, and this author's observations at other San Antonio mission sites agree. In this case, the builder's correction for a slight error in alignment of the foundation shows up in the difference in the amount the foundation projects from the wall above it between Unit A and Unit C.

The bottom of the foundation of the Governor's Palace is deeper than that of the building to the north investigated in 1976. This suggests that they were not built at the same time or for the same purpose. 
This project has demonstrated yet again that any archaeological investigations in the area of the first settlement, no matter how limited, are likely to produce a surprising amount of information about the early history of San Antonio. It is most important to seize every possible chance to expand our knowledge of the earliest times; for which we have so far found little historical documentation. 


\section{References Cited}

Buckley, E. C.

1911 The Aguayo Expedition into Texas and Louisiana, 1719-1722. Quarterly of the Texas State Historical Association, XV(1):1-65.

Chabot, F. C.

1937 With the Makers of San Antonio. Artes Gráficas, San Antonio.

Chipman, D. E.

1992 Spanish Texas 1519-1821. University of Texas Press, Austin.

de la Teja, J. F.

1995 San Antonio de Béxar: A Community on New Spain's Northern Frontier. University of New Mexico Press, Albuquerque.

Foster, W. C.

1995 Spanish Expeditions into Texas 1689-1768. University of Texas Press, Austin.

Fox, A. A.

1977 The Archaeology and History of the Spanish Governor's Palace Park. Archaeological Survey Report, No. 31. Center for Archaeological Research, The University of Texas at San Antonio.

1992 Archaeological Investigations in Alamo Plaza, San Antonio, Bexar County, Texas, 1988 and 1989. Archaeological Survey Report, No. 205. Center for Archaeological Research, The University of Texas at San Antonio.

Fox, A. A., F. A. Bass, Jr., and T. R. Hester

1976 The Archaeology and History of Alamo Plaza. Archaeological Survey Report, No. 16. Center for Archaeological Research, The University of Texas at San Antonio.

Fox, A. A., I. W. Cox, L. Highley, and D. Hafernik

1989 Archaeological and Historical Investigations at the Site of the New Bexar County Justice Center in Downtown San Antonio, Texas. Archaeological Survey Report, No. 184. Center for Archaeological Research, The University of Texas at San Antonio.

Fox, D. E.

1977 Archeological Excavations at San Fernando Cathedral, San Antonio, Texas: A Preliminary Report. Special Report 22. Office of the State Archeologist, Austin.

Giraud, F.

1849 City Engineer's Book, No. 1. Office of Historical Preservation, Main Plaza Building, San Antonio.

Ivey, J. E., and A. A. Fox

1981 Archaeological Survey and Testing at Rancho de las Cabras, Wilson County, Texas. Archaeological Survey Report, No. 104. Center for Archaeological Research, The University of Texas at San Antonio. 
1982 Archaeological Investigations at Mission Concepción and Mission Parkway. Archaeological Survey Report, No. 114. Center for Archaeological Research, The University of Texas at San Antonio. In preparation.

Ivey, J. E., M. B. Thurber, and S. Escobedo

1990 Of Various Magnificence, The Architectural History of the San Antonio Missions in the Colonial Period and the Nineteenth Century, vol. 1. National Park Service Professional Papers No. 11. Santa Fe. Draft on file at the Center for Archaeological Research, The University of Texas at San Antonio.

Jackson, J.

1996a Menchaca, Luis Antonio. In The New Handbook of Texas, edited by R. Tyler, 4:617. Texas State Historical Association, Austin.

1996b Menchaca, José. In The New Handbook of Texas, edited by R. Tyler, 4:616-617. Texas State Historical Association, Austin.

1996c Pérez, Juan Ignacio. In The New Handbook of Texas, edited by R. Tyler, 5:149-150. Texas State Historical Association, Austin

Martin, E.

1931 San Antonio Restores Ancient Palace of Spanish Governors. Pan American Magazine XLIV(3):187-193.

Ramsdell, C.

1959 San Antonio, A Historical and Pictorial Guide. University of Texas Press, Austin.

San Antonio Express [SAE],

1929 Abstract of Title Shows Old Spanish Governor's Palace in Private Hands Since 1804. 2 January.

Santos, R. G. (translator)

1981 Aguayo Expedition into Texas, An Annotated Translation of the Five Versions of the Diary Kept by Br. Juan Antonio de la Peña. Jenkins, Austin.

Schuetz, M. K.

1969 The History and Archeology of Mission San Juan Capistrano, San Antonio, Texas Vol. II. Report 11. State Building Commission Archeological Program, Austin.

Simmons, M., and F. Turley

1980 Southwestern Colonial Ironwork, The Spanish Blacksmithing Tradition from Texas to California. Museum of New Mexico Press, Santa Fe.

Smith, H. P.

1931a Architect Who Restored Palace Appeals to San Antonio to Keep Individuality All Its Own. San Antonio Express, 1 March:4A.

$1931 \mathrm{~b}$ The Restoration of the Spanish Governor's Palace in San Antonio, Texas. Art and Archaeology XXXII (1 and 2):29-34, 48 .

Steele, C

1985 A Journey Through Texas in 1767. El Campanario 16(1). 
Strong, B.

1996 Cassiano, José. In The New Handbook of Texas, edited by R. Tyler, 1:1015. Texas State Historical Association, Austin.

Uecker, H. G., F. K. Meskill, and I. W. Cox

1991 Archaeological Investigations at the Ruiz Family Property (41BX795), San Antonio, Texas. Archaeological Survey Report, No. 198. Center for Archaeological Research, The University of Texas at San Antonio.

Weddle, R. S.

1968 San Juan Bautista: Gateway to Spanish Texas. University of Texas Press, Austin. 


\title{
Appendix A: Analysis of Vertebrate Faunal Remains
}

\author{
Barbara A. Meissner
}

\section{Methods}

A total of 1,952 vertebrate faunal remains was recovered during the project. In the field, bone was recovered by screening the sediment through $1 / 4$-inch mesh. Bones were bagged with other artifacts according to unit and level. In the laboratory, each bone was identified to the lowest possible taxonomic level using the comparative collection at CAR, as well as several standard reference texts (Balkwill and Cumbaa 1992; Gilbert 1990; Hillson 1986; Olsen 1964, 1968). Identifications were conservative, i.e., cow-sized bone was not identified as Bos taurus unless it could be differentiated from both Bison bison (American bison) and Equus sp. (horses, donkeys, and burros). All bone was weighed. Marks on the bone attributable to butchering practices or gnawing by animals were recorded, as was the degree to which the bones were weathered.

In addition to identification of individual specimens, the Minimum Number of Individuals (MNI) was calculated by separating the most abundant paired element for each species into right and left sides, using the greater number of the two as the basic MNI (Grayson 1984:27). Notations concerning element size and the presence of juvenile characteristics were used to refine this estimation. Grayson (1984:29) has pointed out that MNI can vary a great deal depending on how the sample is aggregated. In this case, since levels were arbitrary, all levels of each unit were grouped together.

\section{Analysis}

Twenty-four different taxa were identified to at least the family level. They are listed in Table A-1 with Number of Identified Specimens (NISP), weight in grams, and the MNI.

In general, the bone was in good to fair condition, however a high percentage of bone in the lower levels was highly fragmented and was too small to identify except to the Class level (i.e. Mammalia, Reptilia, etc.). The bone identified to the Family level represented only 9.43 percent (184 of 1952) of the collection. Such highly fragmented bone collections are not uncommon in Colonial period sites in San Antonio, apparently due to trampling and to the deliberate shattering of long bones to extract marrow and to prepare for tallow processing (Hard et al. 1995:82). Only 1.13 percent of the bone shows evidence of burning.

One specimen was of particular interest. This was the lower incisor of a goat (Capra hircus) which has been notched at the border between the enamel and cementum (Figure A-1). The notch is highly polished, as is, to a lesser extent, the enamelcementum neck around the entire tooth, most noticeably on the buccal side. The tooth is extremely worn, with only a small amount of the original enamel still present. The wear does not appear to originate at the occlusal surface, but rather on the lingual side. The occlusal surface, worn away on the lingual side, is quite sharp.

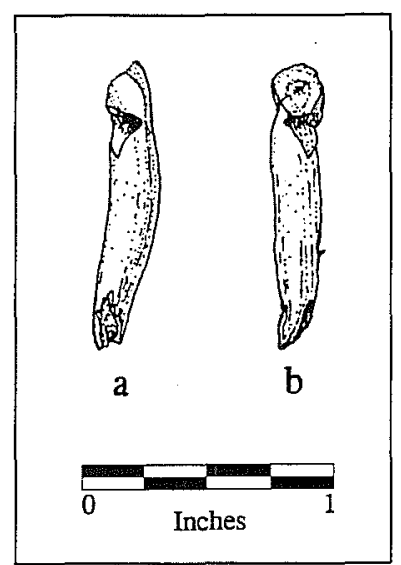

Figure A-1. Notched goat incisor. a-mesial view; $b$-lingual view. Shown actual size.
No record of a similar occurrence in other sites has so far been located in the literature; however, ongoing analyses of large samples of vertebrate remains from two other Colonial period sites in San Antonio have identified similar teeth. Four incisors of Bos taurus (cattle) from Colonial levels in Mission San Juan Capistrano (41BX5) with this pattern of heavy wear, notching and polishing were identified (J. Hunziker, personal communication 1996). Another notched, small artidactyl tooth too worn to identify species was located during an ongoing 
Table A-1. Identified Taxa, NISP, Weight, and MNI

\begin{tabular}{|c|c|c|c|c|c|c|}
\hline Scientific Name & Common Name & Count & $\begin{array}{l}\% \text { of } \\
\text { Total } \\
\text { NISP }\end{array}$ & $\begin{array}{l}\text { Weight } \\
\text { (g) }\end{array}$ & $\begin{array}{l}\% \text { of } \\
\text { Total } \\
\text { ID'ed }\end{array}$ & MNI* \\
\hline Mammalia & \multicolumn{6}{|l|}{ Marumals } \\
\hline Artidactyl (Small) & Deer/goat/sheep & 6 & 3.26 & 26.76 & 2.93 & - \\
\hline Bos taurus & Cattle & 40 & 21.74 & 520.04 & 56.84 & 3 \\
\hline Bovidae & Cattle/Bison & 15 & 8.15 & 291.99 & 31.92 & 3 \\
\hline Canis cf. familiaris & Dog & 2 & 1.09 & 0.27 & 0.03 & 2 \\
\hline Capra hircus & Goat & 2 & 1.09 & 5.99 & 0.65 & 1 \\
\hline Capra/Ovis & Goat/sheep & 1 & 0.54 & 0.92 & 0.10 & - \\
\hline Equus sp. & Horses & 1 & 0.54 & 1.73 & 0.19 & 1 \\
\hline Neotoma cf. albigula & White-throated woodrat & 6 & 3.26 & 1.28 & 0.14 & 1 \\
\hline Neotoma micropus & Southern Plains woodrat & 1 & 0.54 & 0.56 & 0.06 & 1 \\
\hline Neotoma sp. & Woodrats & 3 & 1.63 & 0.48 & 0.05 & 1 \\
\hline Odocoileus virginianus & Whitetail deer & 2 & 1.09 & 18.30 & 2.00 & 1 \\
\hline Peccari tajacu & Collared peccary, javelina & 2 & 1.09 & 0.52 & 0.06 & 1 \\
\hline Rattus rattus & Black rat, roof rat & 73 & 39.67 & 18.22 & 1.99 & 8 \\
\hline Sylvilagus sp. & Cottontail rabbits & 1 & 0.54 & 0.04 & 0.00 & 1 \\
\hline Sus scrofa & Domestic pig & 2 & 1.09 & 4.34 & 0.47 & 1 \\
\hline \multicolumn{2}{|r|}{ NISP Mammals } & 157 & 85.33 & 891.44 & 97.44 & 16 \\
\hline \multirow{2}{*}{\multicolumn{2}{|c|}{$\begin{array}{r}\text { Unidentified Mammals } \\
\text { Total Mammals } \\
\end{array}$}} & 1687 & & 534.00 & & \\
\hline & & 1844 & & 1425.44 & & \\
\hline Aves: & \multicolumn{6}{|l|}{ Birds } \\
\hline Gallus domesticus & Chicken & 11 & 5.98 & 6.30 & 0.69 & 2 \\
\hline Meleagris gallopavo & Turkey & 2 & 1.09 & 0.50 & 0.05 & 2 \\
\hline \multicolumn{2}{|r|}{ NISP Birds } & 13 & 7.07 & 6.80 & 0.74 & 4 \\
\hline \multicolumn{2}{|r|}{ Unidentified Birds } & 32 & & 6.86 & & \\
\hline \multicolumn{2}{|r|}{ Total Birds } & 45 & & 13.66 & & \\
\hline Reptilia & \multicolumn{6}{|l|}{ Reptiles } \\
\hline Pseudomys scripta & Red-eared slider & 1 & 0.54 & 9.70 & 1.06 & 1 \\
\hline Trionix sp. & Soft-shelled turtles & 3 & 1.63 & 2.23 & 0.24 & 2 \\
\hline & NISP Reptiles & 4 & 2.17 & 11.93 & 1.30 & 3 \\
\hline & Unidentified Turtles & 2 & & 0.41 & & \\
\hline & Total Reptiles & 6 & & 12.34 & & \\
\hline
\end{tabular}


Table A-1. continued

\begin{tabular}{|c|c|c|c|c|c|c|}
\hline Scientific Name & Common Name & Count & $\begin{array}{l}\text { \% of } \\
\text { Total } \\
\text { NISP }\end{array}$ & $\begin{array}{l}\text { Weight } \\
\text { (g) }\end{array}$ & $\begin{array}{l}\text { \% of } \\
\text { Total } \\
\text { ID'ed }\end{array}$ & $\mathbf{M N I}^{*}$ \\
\hline Osteichthyes & \multicolumn{6}{|l|}{ Bony Fishes } \\
\hline Aplodinotus grunniens & Fresh water drum & 1 & 0.54 & 0.35 & 0.04 & 1 \\
\hline Ictalurus sp. & Catfish & 2 & 1.09 & 0.48 & 0.05 & 1 \\
\hline Lepososteus sp. & Gar & 3 & 1.63 & 0.36 & 0.04 & 1 \\
\hline Pylodictis olivaris & Flathead catfish & 3 & 1.63 & 3.46 & 0.38 & 2 \\
\hline & NISP Fish & 9 & 4.89 & 4.65 & 0.51 & 5 \\
\hline & Unidentified Fish & 47 & & 7.52 & & \\
\hline & Total Fish & 56 & & 12.17 & & \\
\hline Amphibia & \multicolumn{6}{|l|}{ Amphibians } \\
\hline Rana sp. & Frog & 1 & 0.54 & 0.04 & 0.00 & 1 \\
\hline & NISP Amphibians & 1 & 0.54 & 0.04 & 0.00 & 1 \\
\hline & Unidentified Amphibians & 0 & 0.00 & 0.00 & 0.00 & 0.00 \\
\hline & Total Amphibians & 1 & 0.54 & 0.04 & 0.00 & 1 \\
\hline & Tonal MISI? & 184. & 10000 & 99486 & & $2 \%$ \\
\hline & 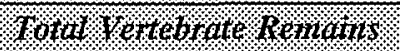 & 1982. & & $(1463 \% 68$ & & 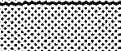 \\
\hline
\end{tabular}

* MNI calculated for taxa at genus and/or species level only.

analysis of a Colonial bone bed from Alamo Plaza (41BX438) by this author. It looks very much like the tooth from this collection, although more worn, with very little enamel remaining.

The most likely explanation for the tooth is that it was used as a tool of some sort. Further research will be necessary to determine if similar finds have been made in other sites in North America, or if this is a practice confined to San Antonio during the Colonial period.

\section{Comparison of Colonial and Post-Colonial Levels}

For the purposes of this analysis, the bone was divided into three groups and the categories compared. Bone in unit/levels which contained only Colonial-period (Unit/Level B/4, B/5, and C/4-C/6), were placed in the "Colonial" category. Bone from levels containing both Colonial and post-Colonial artifacts (Unit/Level A/3, A/4, B/3, and $\mathrm{C} / 3$ ) were placed in the "Mixed" category, and bone from unit/levels containing only post-Colonial artifacts (Unit/Level A/1, A/2, B/1, B/2, C/1, and $\mathrm{C} / 2$ ) was placed in the "post-Colonial" category. Table A-2 shows taxa identified to the family level by these three categories.

Sample size is well known to have a profound effect on measures of taxonomic richness, i.e. the number of different taxa identified in a sample (Grayson 1984:132) and, to a lesser degree, the relative abundance (Grayson 1984: 117). The small size of this collection limits its analytic utility in comparison to other Colonial-period sites with much larger sample sizes. Comparison of the three categories within this collection can be made, since the bone is fairly evenly divided between the three categories (Colonial $=33$ percent, mixed $=29$ percent, and postColonial $=39$ percent of the total NISP). However, 
Table A-2. Identified Taxa Divided into Colonial, Mixed, and Post-Colonial Categories

\begin{tabular}{|c|c|c|c|c|c|c|}
\hline \multirow{2}{*}{ Taxon } & \multicolumn{2}{|c|}{ Colonial } & \multicolumn{2}{|c|}{ Mixed } & \multicolumn{2}{|c|}{ Post-Colonial } \\
\hline & NISP & $\%$ & NISP & $\%$ & NISP & $\%$ \\
\hline Artidactyl (small) & 3 & 5.00 & 3. & 5.66 & 0 & 0.00 \\
\hline Bos taurus & 27 & 45.00 & 9 & 16.98 & 4 & 5.63 \\
\hline Bovidae & 8 & 13.33 & 7 & 13.21 & 0 & 0.00 \\
\hline Canis cf. familiaris & 2 & 3.33 & 0 & 0.00 & 0 & 0.00 \\
\hline Capra hircus & 2 & 3.33 & 0 & 0.00 & 0 & 0.00 \\
\hline Capra/Ovis & 0 & 0.00 & 0 & 0.00 & 1 & 1.41 \\
\hline Equus sp. & 1 & 1.67 & 0 & 0.00 & 0 & 0.00 \\
\hline Neotoma cf. albigula & 0 & 0.00 & 0 & 0.00 & 6 & 8.45 \\
\hline Neotoma micropus & 1 & 1.67 & 0 & 0.00 & 0 & 0.00 \\
\hline Neotoma sp. & 2 & 3.33 & 0 & 0.00 & 1 & 1.41 \\
\hline Odocoileus virginianus & 2 & 3.33 & 0 & 0.00 & 0 & 0.00 \\
\hline Peccari tajacu & 1 & 1.67 & 1 & 1.89 & 0 & 0.00 \\
\hline Rattus rattus & 0 & 0.00 & 22 & 41.51 & 51 & 71.83 \\
\hline Sylvilagus sp. & 0 & 0.00 & 1 & 1.89 & 0 & 0.00 \\
\hline Sus scrofa & 0 & 0.00 & 2 & 3.77 & 0 & 0.00 \\
\hline Total Identified Mammals & 49 & 81.67 & 45 & 84.91 & 63 & 88.73 \\
\hline Gallus domesticus & 3 & 5.00 & 3 & 5.66 & 5 & 7.04 \\
\hline Meleagris gallopavo & 0 & 0.00 & 0 & 0.00 & 2 & 2.82 \\
\hline Total Identified Birds & 3 & 5.00 & 3 & 5.66 & 7 & 986 \\
\hline Pseudomys scripta & 1 & 1.67 & 0 & 0.00 & 0 & 0.00 \\
\hline Trionix sp. & 2 & 3.33 & 1 & 1.89 & 0 & 0.00 \\
\hline Total Identified Reptiles & 3 & 5.00 & 1 & 1.89 & 0 & 0.00 \\
\hline Aplodinotus grunniens & 0 & 0.00 & 1 & 1.89 & 0 & 0.00 \\
\hline Ictalurus sp. & 2 & 3.33 & 0 & 0.00 & 0 & 0.00 \\
\hline Lepososteus sp. & 2 & 3.33 & 0 & 0.00 & 1 & 1.41 \\
\hline Pylodictus olivaris & 1 & 1.67 & 2 & 3.77 & 0 & 0.00 \\
\hline Total Identified Fish & 5 & 8.33 & 3 & 5.66 & 1 & 1.41 \\
\hline Rana sp. & 0 & 0.00 & 1 & 1.89 & 0 & 0.00 \\
\hline Total Identified Amphibians & 0 & 0.00 & 1 & 1.89 & 0 & 0.00 \\
\hline Ioral vis?: & 69 & $1000 \%$ & 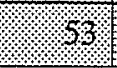 & 100.901 & $7 \%$ & 1000 \\
\hline
\end{tabular}


the comparison must still be made with the small size of the overall collection in mind. Perhaps the most striking difference between Colonial and postColonial bone is that 71.83 percent of the identified post-Colonial bone is Rattus rattus, the black or roof rat, while no $R$. rattus was recovered in the Colonialperiod bone. This species is an immigrant from Europe, most common in seaports in the New World (Davis and Schmidly 1994:198). It has been found in nineteenth- and early twentieth-century sites in San Antonio (Meissner and Hunziker 1997), sometimes in great abundance (Meissner 1997).

The near absence of $R$. rattus in Colonial period sites in San Antonio (Davidson and Clark 1978:136; Hard et al. 1995:83; Lundelius 1969:113-115) with the only exception being a single mandible in an eighteenth-century midden (Rawn 1977:Table I-2) suggests that this rat did not get established in the area until post-Colonial times.
Another notable difference between Colonial and post-Colonial bone in this site is the lack of diversity in the post-Colonial taxa. Seventeen taxa are represented in the Colonial category, while only eight are present in the post-Colonial deposit. As might be expected, the Mixed category is between the two, with 11 taxa identified.

A third difference in the two categories is evident from Table A-3. The animals identified in postColonial context are overwhelmingly nondomesticated, while the animals from Colonial periods are largely domestic. Again, the mixed category is about evenly divided between the two.

The fourth difference is seen in the butchering techniques used on domestic animals, especially cattle. Butchering marks noted on identified elements of cattle and cattle-sized bone are listed in Table A-4, which clearly show the shift in butchering techniques

Table A-3. Domestic vs. Non-domestic Taxa

\begin{tabular}{|c|c|c|c|c|c|c|}
\hline & \multicolumn{2}{|c|}{ Colonial } & \multicolumn{2}{c|}{ Mixed } & \multicolumn{2}{c|}{ Post-Colonial } \\
\hline Animal Type & NISP & $\%$ & NISP & $\%$ & NISP & $\%$ \\
\hline Domestic & 43 & 75.44 & 21 & 42.86 & 12 & 16.90 \\
\hline Non-domestic & 14 & 24.56 & 28 & 57.14 & 59 & 83.10 \\
\hline Total & 57 & 100.00 & 49 & 100.00 & 71 & 100.00 \\
\hline
\end{tabular}

Note: NISP in this table does not include the small artidactyls, as these bones could be from either wild deer or domestic sheep or goat.

Table A-4. Butcher Marks on Cattle-sized Bone

\begin{tabular}{|l|c|c|c|}
\hline \multicolumn{1}{|c|}{ Butchering Mark } & Colonial & Mixed & Post-Colonial \\
\hline Machine saw cut & & & 1 \\
\hline Hand saw cut & & 3 & 1 \\
\hline Saw cut (indeterminate) & & 1 & 2 \\
\hline Thin cut & 1 & & \\
\hline Thick cut (superficial) & 2 & & \\
\hline Chop (deep) & 12 & 3 & \\
\hline Impact scar & 4 & 1 & \\
\hline
\end{tabular}


from Colonial to post-Colonial time periods. All postColonial cattle bone are cut in a fashion still in use today. Further evaluation of butchering patterns would not be useful, as the sample size is so small.

\section{Conclusion}

Though the small size of this collect limits the inferences that can be reliably drawn from it, a few observations can be made. Distinct differences in the bone assemblages are seen. Bone from the postColonial levels has limited diversity and is largely from small rodents (82 percent), with the remainder consisting mostly of domestic animals commonly used for food. In contrast, the Colonial period bone has twice the diversity of taxa, yet 66 percent of the identified bone was domestic animals commonly used for food, and another 18 percent consists of wild animals commonly used for food. The impression left by the two categories is that the Colonial period bone represents domestic trash, while the post-Colonial bone is mostly of commensal animals, with only a few examples of remains from domestic trash. In actuality the building continued in use as a residence until the mid-1800s. However, trash such as animal bone was probably not allowed to accumulate outside the front door and along the plaza side much beyond 1823 when the Governor's Palace became the home of Maria Gertrudis Pérez and the former governor, Manuel Cordero. 


\section{References Cited}

Balkwill, D. M., and S. L. Cumbaa

1992 A Guide to the Identification of Postcranial Bones of Bos taurus and Bison bison. Canadian Museum of Nature, Ottawa.

Davidson, B., and J. W. Clark

1978 Faunal Analysis. In Mission San José y San Miguel de Aguayo: Archaeological Investigations, December 1974, edited by J. W. Clark, pp. 135-193. Office of the State Archeologist, Austin.

Davis, W. B., and D.J. Schmidly

1994 The Mammals of Texas. Texas Parks and Wildlife, Austin.

Gilbert, B. M.

1990 Mammalian Osteology. Missouri Archaeological Society, Columbia.

Grayson, D. K.

1984 Quantitative Zooarchaeology: Topics in the Analysis of Archaeological Fauna. Academic, New York.

Hard, R. J., A. A. Fox, I. W. Cox, K. J. Gross, B. A. Meissner, G. Mendez, C. L. Tennis, and J. Zapata 1995 Excavations at Mission San José y Miguel de Aguayo, San Antonio, Texas. Archaeological Survey Report, No. 218. Center for Archaeological Research, The University of Texas at San Antonio.

Hillson, S.

1986 Teeth. Cambridge University Press, Cambridge.

Lundelius, E. L.

1969 Analysis of Nonhuman Bone Material from San Juan Capistrano Mission. In The History and Archeology of Mission San Juan Capistrano, San Antonio, Texas, vol. II, edited by M. Schuetz, pp. 110-115. Archeological Program Report No. 11. State Building Commission, Austin.

Meissner, B. A.

1997 The Alamo Restoration and Conservation Project: Excavations at the South Transept. Archaeological Survey Report, No. 245. Center for Archaeological Research, The University of Texas at San Antonio.

Meissner, B. A., and J. M. Hunziker

1997 Analysis of the Vertebrate Faunal Remains from the Alamodome Project. In Archaeology at the Alamodome: Investigations of a San Antonio Neighborhood in Transition, Volume III: Artifact and Special Studies, edited by A. A. Fox, M. Renner, and R. J. Hard, pp. 289-358. Archaeological Survey Report, No. 238. Center for Archaeological Research, The University of Texas at San Antonio. In press. 
Olsen, S. J.

1964 Mammal Remains from Archaeological Sites Part I; Southeastern and Southwestern United States. Peabody Museum, Cambridge.

1968 Fish, Amphibian, and Reptile Remains from Archaeological Sites Part I: Southeastern and Southwestern United States. Peabody Museum, Cambridge.

Rawn, V. M.

1977 Analysis of Bone Material. In An Archaeological Investigation of Mission Concepción, San Antonio, Texas, edited by D. Scurlock and D. E. Fox, pp. 143-152. Report 28. Office of the State Archeologist, Austin. 

